\title{
STUDENT MATURITY AND MOTIVATION: A CASE FOR THE ASSESSMENT OF ONLINE (DISTANCE LEARNING) EDUCATION
}

\author{
Saviour L. S. Nwachukwu, Southern University and A\&M College saviour_nwachukwu@subr.edu
}

\begin{abstract}
The growth in online education is significant, and experts predict that the current level of growth will continue for the foreseeable future. Online education provides opportunities for a large number of students who would otherwise not be able to advance their education and training. However, there is evidence to suggest that online distance learning is more suitable and beneficial for individuals who are mature and exhibit a reasonable level of self-motivation. This paper argues that traditional colleges and universities that offer courses in face-to-face classroom settings should review their online programs and perhaps restrict access to these programs only to those students who are likely to succeed in them - i.e., mature and self-motivated students. The rationale for this argument is that students that need face-to-face instructions and assistance in order to succeed, should be required to take needed courses in a traditional classroom settings, however, sufficient resources (both physical and online) should be made available to all students.
\end{abstract}

Keywords: Online Education, Social Cognitive Theory, Academic Advising

\section{INTRODUCTION}

Online education is growing rapidly. According to a survey by the Sloan Consortium, about 2.4 million students were taking one or more online courses in the U.S. in the fall of 2008; up from 1.6 million in 2002 [21]. Other estimates put the number of online students at much higher levels - for example Clark [9] noted that more than four million Americans enrolled in an online course during the autumn of 2008, as compared to less than two million during the autumn of 2003. There is a general agreement that the number of students enrolling in online courses, certificate programs, or full degree programs is growing rapidly world-wide, and will continue to grow in the foreseeable future.

\section{PURPOSE OF THE PAPER}

This paper presents a discussion of the implications of the moderating effects of two important factors that have been found to be associated with students success in online courses - maturity and motivation. This paper examines the appropriateness of the strategy to offer online courses (and certificate and degree programs) by colleges and universities simply as a reaction to market forces. It is argued that online courses and programs should be offered by traditional colleges and universities after a thorough and careful analysis of the benefits of those programs to the student populations - particularly, as their success (or failure) is likely to be influence by their maturity and motivation.

\section{FACTORS DRIVING THE GROWTH OF ONLINE PROGRAMS}

Several factors have been identified as influencing the growth of online education. However, the major factors cited in the literature include: (a) the need for career advancement opportunities, (b) flexibility, (c) competition among colleges and universities, (d) budget constraints facing colleges and universities, and (e) technological advancement - internet broadband, wireless and WiFi enabled devices. 
Volume XII, No. 2, pp 244-249, 2011

\section{Need for Career Advancement Opportunities}

There has always been a need by individuals to set themselves apart from their peers as they pursue career opportunities and advancement. This need has contributed to the rapid growth in online education, particularly for business degrees, both at the undergraduate and graduate levels $[3,38]$. In addition, online education appeals to employers for some of the same reasons. Distance education provides a more knowledgeable workforce that would otherwise not pursue higher education due to time or geographic constraints [38].

\section{Flexibility}

Online courses and degree programs provide convenience and flexibility that traditional face-to-face classroom instructions do not offer [38]. Students can study whenever they want (night or day), for as long as they want, and wherever they happen to be. It is the perfect solution not only for professionals who are working in demanding jobs, but, also for individuals caring for children, or living far from an actual college location [2, 4, 17, 42]. For some students, online education is not only more convenient, but it may be the only option available to them [21].

\section{Competition among Colleges and Universities}

Though many of the top colleges and universities in the U.S.A. have not rushed to offer online courses and degree programs for fear of diminishing their hard earned reputation, many public colleges and universities, on the other hand, are already offering online courses, certificates, and degree programs. It is argued that, the more a college (or university) feels that it is at a disadvantage in attracting good students, the more likely the college will offer online courses, certificates, and/or degree programs.

\section{Budget Constraints Facing Colleges and Universities}

For some time now, public funds earmarked for higher education has been declining; and colleges and universities have been forced to increase tuition and other fees. However, tuition increases are rapidly reaching the point where they cannot keep up with the decreases in federal, state, and local financial support. The increasing cost of delivering instructional content through traditional means has also been cited as a driving force for the growth of online learning [42]. The high cost of constructing new facilities to meet growing demand - particularly by adult and professional students - has placed severe limits on adding new classroom space to meet that demand.

Online programs offer colleges and university the opportunity to significantly increase student population with modest increases in their budgets.

\section{Technological Advancement - Internet Broadband, Wireless and WiFi Enabled Devices}

Not long ago, distance learning programs were called "correspondence courses," and teachers and students communicated by "regular" mail [41]. However, only a few determined students were able to successfully complete the courses. This is because, typically, correspondence courses tended to have more assignments and home work than regular classes, and the final exams tended to be comprehensive in nature - i.e., students are tested on all the materials they should have read and mastered. These two characteristics did not particularly appeal to many students.

However, in the current environment, the rapid growth in online education is being fueled by advancement in internet technology - e.g., broadband and wireless connectivity, mobile technology. In addition, the ubiquity of the technology is making it easier and easier to access online contents through a variety of means - e.g., podcasting, message boards, email, iTunes U, wikis, virtual classrooms, etc. [19, 29]. 
Volume XII, No. 2, pp 244-249, 2011

\section{STUDENT SUCCESS FACTORS IN ONLINE PROGRAMS}

\section{Maturity}

Student maturity has been identified as a major success factor in online courses and programs. In his study of performance factors in distance learning programs, Koch [19] reported that student age was a factor - i.e., the older the student, the better grade he/she is likely to earn. Similar findings have been reported previously - e.g., Dille and Mezack [11]. In their study, Beqiri, Chase and Bishka [4] reported that the profile of students who are more likely to be satisfied with online courses include: graduate, married, male, and students who resides more than 1 mile away from campus [3]. Maturity is an important moderating factor in distance learning outcomes because it fosters the discipline that is needed to focus in an individualized self-directed learning environment.

\section{Motivation}

Participation in an online course or program introduces its own set of challenges. A high level of motivation is required to complete self-study courses; discipline is needed to complete long-term assignments; and for synchronous online programs - those in which online "contacts" are required with a teacher in real time - students still have to make time to attend classes. Online students have to be able to filter out the multitude of environmental factors that can serve as distractions [3].

In their study, Meissonier, Houzé, Benbya and Belbaly [26] identified motivation and self discipline of students as main drivers of e-learning outcomes. Also, in their survey of career and technical educators, Russ, Mitchell \& Durham [32] reported that career and technical educators believe that self-motivation and the ability to work independently are the two most important factors for success in online learning.

\section{THE NEED TO MATCH STUDENT CHARACTERSITICS WITH ONLINE COURSES AND PROGRAMS}

There many concerns that have been raised with respect to the proliferation of online courses and programs. These include the assurance of quality of the programs being offered, fraud and scams perpetrated by unscrupulous "online only" colleges and universities, and the legitimacy of students work [14]. However, the main focus of this paper is on the necessity (for traditional colleges and universities) to align online courses and programs with student characteristics - that is, offer online courses and programs only to students who are more likely to succeed in such programs, and consequently, benefit from them.

If the major factors identified as necessary for success in online courses are analyzed carefully, then the question might arise whether or not colleges and universities should only allow students who are more likely to succeed in the online programs to participate. In a typical university environment, maturity and motivation manifest themselves in many different ways; however, it can be argued that students' grade point average can serve as a good proxy. Therefore, students that meet a certain minimum GPA can enroll in a particular online course, and those that fall below that minimum, can also enroll in the same course, provided they also attend a certain minimum number of face-to-face classroom instructions.

There are many colleges and universities that generally attract students with average (and less than average) scores on entrance exams (e.g., SAT, ACT, etc.). These institutions should adapt their online offerings to address the particular needs of their student populations. These categories of instutions should not simply react to changes in the marketplace and join other colleges in offering online programs.

The appropriateness of online (distance learning) education has also been questioned with respect to specific areas of studies and particular types of courses. In an analysis of the use of distance learning (online courses) in Business Communication courses, Wardrope [39] noted that: 
... the prospect of using distance education to teach business communication raises questions: Can distance education serve as an effective medium for teaching business communication content, much of which is interactive? Can distance education motivate our students to be good business communicators?

Similar concerns had previously been echoed by various researchers - [12]:

distance learning is contrary to current pedagogical theories of business communication such as team building, mentoring, people skills, and group discussion. These interactive competencies, rather than technical skills, are the abilities that employers still tell us their employees need [31]. Research still holds that most of the skills required in the workplace are communication-based [39], that the ability to communicate is the single most important employment skill [24, 25, 27, 28-29, ], and that communication ability is more important than technical expertise [7].

There is empirical evidence to support these arguments. In their study of a hybrid course (online and optional faceto-face class meeting) offered by the Open University of Hong Kong, Cheung and Kan, [8] found that students who attended the optional face-to-face classrooms meetings performed better than those who opted not to attend.

\section{TRADITIONAL (FACE-TO-FACE) VS. ONLINE (DISTANCE LEARNING) ENVIRONMENT - THE CASE AGAINST USING STUDENT CHARACTERISTICS}

Many studies have examined students' performance in a traditional (face-to-face) classroom environment versus online (distance) learning environment. However, these studies have generally reported no statistical differences in final course grades earned, and/or test scores [1, 9, 15, 18, 33]. In addition to these studies, there are those that have reported better performance for the traditional classroom groups [6, 17, 19, 34]; and there are even those studies that have reported better performance by the online (distance) learning groups [35, 36]. Taken together, the general proposition seems to be that there is no statistical differences between students in traditional face-to-face classroom environment and those who complete the same course in a distance learning (online) environment.

However, according to Koch [19] the majority of these studies have a fundamental weakness - generally, the research designs did not include control groups - that is, students should take identical course from the same professor, and at the same time; and complete the same tests, in the same test location, at the same time,( italics added). In addition, Machtmes \& Asher [23] argue that even for many of the studies that do include control groups, they suffer from other methodological problems such as differing instructional content or faculty members.

It is the contention of this paper that the debate misses the point completely. The idea of belaboring the point that there are no statistical differences in final grades earned and/or test scores between students in traditional face-toface classroom settings and those who complete the same course in a distance learning (online) environment is analogous to stating that:

Our low achievement students are performing poorly in classroom settings to the same degree as they are performing in online settings; therefore, we should allow them to take online courses.

A major goal of all educational institutions is to provide the best learning environment for all their students - those who demonstrates high levels of maturity and self-motivation can enroll in online courses and those who need closer supervision and assistance should be required to enroll in traditional face-to-face classes; however, sufficient resources should be provided to all students - both in person and online.

This paper argues that traditional colleges and universities should examine and consequently utilize online technologies and strategies that provide the means for improving the performance of all students, particularly those who have exhibited the need for additional attention; and if there are resources online that can help those students, then the institutions should employ them; however, if online technologies merely replicates poor classroom 
performances, then the institution should seriously reconsider, particularly since there are evidence to suggest that classroom interactions provides benefits that cannot be obtained in online settings - e.g., the opportunity to interact with another individual on a face-to-face basis. As Wardrope [39] argues, interaction in the classroom is important not only for the purposes of cognitive learning but for affective development as well. As noted by MacDonald and McNabb [22], adoption of a new knowledge delivery model must be a reflection of what best meets the needs of all stakeholders; and an important component of the adoption process, is identification of an instructional design that is right for the students, the university, the faculty, and the subsequent employers of the graduates. The concerns of the course designer and instructor are to ensure that the best elements of all available approaches are implemented wherever possible. Consequently, a blend of face-to-face (classroom) and online (distance learning) approaches may well be the best strategy [22, 42].

\section{REFERENCES}

1. Abraham, T. (2002). Evaluating The Virtual Management Information Systems (MIS) Classroom. Journal of Information Systems Education, vol. 13, no. 2, pp. 125-133.

2. Alstete, J. W. and N. J. Beutell (2004). Performance Indicators in Online Distance Learning Courses: A Study of Management Education. Quality Assurance in Education, Vol. 12, No. 1, pp. 6-14.

3. Anderson, Wayne (2008). Online Degrees: Are They Right for You? Certification Magazine, (June), pp. 18-23.

4. Beqiri, Mirjeta S., Nancy M. Chase and Atena Bishka (2010). Online Course Delivery: An Empirical Investigation of Factors Affecting Student Satisfaction. Journal of Education for Business, Vol. 85, pp. 95-100.

5. Bianchi, Michael (2011). The Cyber Classroom: A Mashup of Lecture and Distance Learning Improves Student Performance. Streaming Media Industry Sourcebook, pp. 128-130

6. Brown, B. W. and C. E. Liedholm (2002). Can Web Courses Replace the Classroom in Principles of Microeconomics? Teaching Microeconomic Principles, Vol. 92, no. 2, pp. 444-448.

7. California State University. (2000). Employers' Demand for Skills [Online]. Available: www.des.calstate.edu/scans.html.

8. Cheung, Lenis L.W. and Andy C. N. Kan (2002). Evaluation of Factors Related to Student Performance in a Distance-Learning Business Communication Course. Journal of Education for Business. (May/June), pp. 257-263

9. $\quad$ Clark, Kim (2009). E-Learning Clicks with Students. U.S. News \& World Report, May, Vol. 146, Issue 4, pp. 48-50

10. Dellana, S. A., W. H. Collins and D. West (2000). On-Line Education In A Management Science Course Effectiveness and Performance Factors. Journal of Education for Business, Vol. 76, No. 1, pp. $43-47$.

11. Dille, Brian; Mezack, Michael (1991) Identifying Predictors of High Risk Among Community College Telecourse Students. American Journal of Distance Education, Vol. 5, No. 1, pp. 24-35.

12. Dyrud, M. A. (2000). The Third Wave: A Position Paper. Business Communication Quarterly, vol. 63, no. 3, pp. 81-93.

13. Fisher, Anne - askannie@fortunemail.com (2003). Will I End Up Getting Scammed if I Pursue an Online MBA? Fortune, 9/29/2003, Vol. 148, Issue 6, p. 170.

14. Gilmore, Agatha (2008). Online Degrees: Friend or Foe? Certification Magazine, October, p. 14

15. Heines, R. A. and D. B. Hulse (1996). Two-Way Interactive Television: An Emerging Technology for University Level Business School Instruction. Journal of Education for Business, vol. 72, no. 2, pp. 74-77.

16. Hiltz, Starr Roxanne and Murray Turoff (2005). Education Goes Digital: The Evolution of Online Learning and the Revolution in Higher Education. Communications of the ACM, October, Vol. 48, No. 10, Pp. 59-64

17. Kan, Andy C. N. and Lenis LM. Cheung (2007). Relative Effects of Distance versus Traditional Course Delivery on Student Performance in Hong Kong. International Journal of Management, Vol. 24, No. 4, December, pp. 763-773.

18. Kekkonen-Moneta, S. and G. B. Moneta (2002). E-Learning in Hong Kong: Comparing Learning Outcomes in Online Multimedia and Lecture Versions of an Introductory Computing Course. British Journal of Educational Technology, Vol. 33, No. 4, pp. 423-433. 
19. Koch, James V. (2006). Public Investment in University Distance Learning Programs: Some PerformanceBased Evidence. Atlantic Economic Journal, Vol. 23, pp. 23-32.

20. Krakovsky, Marina (2010). Degrees, Distance, and Dollars. Communications of the ACM, vol. 53 (no. 9), pp. 18-19.

21. Lord, Mary (2001). No Need to Lose the Lifestyle. U.S. News \& World Report, 04/09/2001, Vol. 130, Issue 14, p. 66, 2p

22. MacDonald, D. B., and D. E. McNabb (2006). Developing a Blended Model for MBA Content Delivery: Using Internet Capabilities to Enhance Graduate Education. Proceedings of the 2006 Academic Business World International Conference, Nashville, Tennessee.

23. Machtmes, Krisanna and J. William Asher (200). A Meta-Analysis of the Effectiveness of Telecourses in Distance Education. American Journal of Distance Education, Vol. 14, No. 1, pp. 27-46.

24. Maes, J. D., T. G. Weldy and M. L. Icenogle (1997). A Managerial Perspective: Oral Communication Competency is Most Important for Business Students in the Workplace. Journal of Business Communication, Vol. 34, No. 1, pp. 67-80.

25. McPherson, B. (1998). Student Perceptions about Business Communication in their Careers. Business Communication Quarterly, Vol. 6, No. 2, pp. 68-79.

26. Meissonier, Régis, Emmanuel Houzé and Hind Benbya (2006). Performance Factors of a "Full Distance Learning”: The Case of Undergraduate Students in Academic Exchange. Communications of AIS, Vol. 18.

27. Plutsky, S. (1996). Faculty Perceptions of Students' Business Communication Needs. Business Communication Quarterly. Vol. 59, No. 4, pp. 69-76.

28. Reinsch, L. and A. N. Shelby (1996). Communication Challenges and Needs: Perceptions of MBA Students. Business Communication Quarterly. vol. 59, no. 1, pp. 36-63.

29. Reinsch, L. and A. N. Shelby (1997). What Communication Abilities Do Practitioners Need? Evidence from MBA Students. Business Communication Quarterly, vol. 60, no. 4, pp. 7-29.

30. Rich, Lisa Logan, Wendy Cowan and Susan D. Herring (2009). Removing the "Distance" from Distance Education: Strategies for Successful Student Engagement and Collaboration. Proceedings of the Allied Academies Internet Conference, Vol. 11, pp. 84-88

31. Roever, C. (1999). Arguments for Focusing on Our Core Business. Business Communication Quarterly, Vol. 62, No. 2, pp. 86-89.

32. Russ, Carolyn L., Geana W. Mitchell and Sandra K. Durham (2010). Components that Affect Success in Distance Learning as Perceived by Career and Technical Educators. Business Education Innovation Journal, Vol 2 (no. 2), pp. 73-79.

33. Ryan, W. F. (1996). The Effectiveness of Traditional Vs. Audiographics Delivery in Senior High Advanced Mathematics Courses. Journal of Distance Education, vol. 11, no. 2, pp. 45-55.

34. Sauers, D. and R. C. Walker (2004). A Comparison of Traditional and Technology-Assisted Instructional Methods in the Business Communication Classroom. Business Communication Quarterly, vol. 67, no. 4, pp. 430-442.

35. Scay, R. A. and M. I. Milman (1994). Interactive Television Instruction: An Assessment of Student Performance and Attitudes in an Upper Division Accounting Course. Issues in Accounting Education, Vol. 9, No. 1, pp. 80-95.

36. Schutte, J. G. (1997). Virtual Teaching in Higher Education: The New Intellectual Superhighway or Just Another Traffic Jam? <http://www.csun.edu/sociology/virexp.htm>.

37. Solomon, Janet Stern (2007). Evaluating the Validity of Online Degrees Key to Successful Tuition Benefits. Employee Benefit News, June 1, p. 64.

38. Studt, Tim (2011). Keying In on Online Colleges. Academic Sourceguide, April, p. 29.

39. Wardrope, William J. (2001). A Communication-Based Response to Distance Learning in Business Communication. Business communication Quarterly, Vol. 64, No. 2, pp. 92-97.

40. Wilhelm, William J. (1999). A Delphi Study of Entry-Level Workplace Skills, Competencies, and Proofof-Achievement Products. Delta Pi Epsilon Journal, Vol. 41 (Spring), No. 2, pp. 105-122

41. Wyoming Business Report (2010). Choosing a Distance Learning Program. Nov., p. 7B

42. Zabriskie, Fern H. and David E. McNabb (2007). E-hancing the Master of Business Administration (MBA) Managerial Accounting Course. Journal of Education for Business, pp. 226-233. 